\title{
'People and personal projects': a rejoinder on the challenge of teaching development studies
}

\section{Wendy Harcourt}

To cite this article: Wendy Harcourt (2018): 'People and personal projects': a rejoinder on the challenge of teaching development studies, Third World Quarterly, DOI:

10.1080/01436597.2018.1460595

To link to this article: https://doi.org/10.1080/01436597.2018.1460595

曲 Published online: 08 May 2018.

Submit your article to this journal $\pi$

Џ Article views: 48

Q View related articles $₫$

View Crossmark data $\asymp$ 


\title{
'People and personal projects': a rejoinder on the challenge of teaching development studies
}

\author{
Wendy Harcourt \\ International Institute of Social Studies, Erasmus University, The Hague, The Netherlands
}

\begin{abstract}
In response to Juan David Parra Heredia's criticism of her earlier article about her use of post-development as a tool in teaching development studies, Wendy Harcourt reflects further on how the course analysed in 2016 has evolved in the last three years and corrects the misreadings of the pedagogical position-taking by the teachers in the course.
\end{abstract}

\author{
ARTICLE HISTORY \\ Received 30 March 2018 \\ Accepted 30 March 2018 \\ KEYWORDS \\ Post-development \\ risk \\ pedagogy \\ development studies
}

I was interested, if somewhat bemused, to be asked to review the article by Juan David Parra Heredia reflecting on my piece 'The Making and Unmaking of Development: Using PostDevelopment as a Tool in Teaching Development Studies." ${ }^{11}$ As he himself notes he is a member of the same International Institute of Social Studies (ISS) community, and although he was not a student of mine and had not attended the course, he had 'actively engaged in conversations with its participants (in the corridors, other lectures, in the bar).' ${ }^{2}$ However, as I now head into the fourth year of teaching the course, with very positive student evaluations and equally positive external evaluations, I welcome the chance to reflect further on how the course has evolved as well as to comment on what I would suggest is a misreading of some aspects of what I and the teaching team aim to achieve in what is affectionately known by the students as 'MoD' (Making of Development).

I begin by quoting from the most recent comment on the course by one of the Economics major students - who took the second year of MoD and was a facilitator for the third year:

I want to thank you for the risks you take ... You take a risk because of your teaching method. You take a risk when you let everybody express their own opinion, not knowing who is on the other side. You take a big risk with every single class you teach ... Given your status, you could easily rest and take no risks at all. You could teach in an 'ordinary' way. It wouldn't be the same for you, I am sure, but you could do it and nobody would demand you to change it. So, thank you for being 'extraordinary'. Please, keep taking risks. Now more than ever. You can't imagine how students treasure the professors willing to take the kind of risks you take. ${ }^{3}$

It is these kinds of comments from students in the last three years which have kept me convinced that using post-development as a tool box, inspired by Paolo Freire, bell hooks and Arturo Escobar, as I describe in my article, is producing a course that is successfully engaging students pedagogically and politically. 
That being said, the course has evolved based on conversations with students - in the formal evaluations and informal reviews as well as the regular in-depth discussions with the three sets of student facilitators - towards the direction that Parra Heredia might well approve where post-development becomes one of the contested ways through which to understand development as a set of cultural, political, economic and historical processes and relations. Students are still expected to share and seek to understand more deeply their encounters with development, but post-development as a theory emerges at the end of the course. The course now has three modules, which focus on narratives of economic development, people and place in development, and post-development and alternatives to development. Emphasis is on the students' engagement with the course literature, course lectures and their own experience as they learn to analyse development as an historical process, an aspiration, a discourse of power and a set of practices.

The major success of the course continues to be the peer-to-peer workshops run by students who volunteer to facilitate after completing the course. This is a competitive process as there are many more volunteers than there are places. The workshop groups are now smaller and the different exercises following the themes of the lecture more honed in terms of how to encourage co-learning and dialogue. The development dictionary entry exercise (where students create a group project video) has led to some excellent (and very funny) 'MoD' videos - many of which show great perception in criticising the course literature and positions of the teachers. The course continues to emphasise an open learning environment, using participatory interactive methodology, and it is now running well, with greater confidence in the course by both teachers and students than when it ran in its first year. Instead of critical remarks in the corridors (or bar) there are requests by colleagues to join the teaching group.

While I do not wish to comment on critical realism, on which Parra Heredia bases his own teaching and which he presents as a substantive criticism of post-development, may I point out that Parra Heredia misrepresents how the course interprets the role of the teachers both the academic staff and the workshop facilitators. The teaching staff clearly situate our knowledge as stemming from our own disciplines, experience, contexts and ideas; while we still engage in dialogue, we most definitely contend that we speak from positions of knowledge even if not quite using the term 'immanent authority'. We also speak about different forms of privilege - those that we construct, and are constructed by, in and outside the classroom - that reflect class, geography, gender and race. Such openness about situated knowledge is an important part of the course reflections of the making, unmaking and remaking of development in the ISS development studies context. In this, the course follows feminist theorists Donna Haraway and Sandra Harding who acknowledge the importance of the interlocutor in describing and analysing experience and who bring attention to knowledge as embodied and historically specific and therefore contestable, whatever the scientific and technological constructions and claims. ${ }^{4}$ We teach development as part of the

epistemologies of location, positioning and situating where partiality and not universality is the condition of being heard to make rational knowledge claims. These are claims on people's lives: the view from a body - always a complex, contradictory, structuring and structured body. ${ }^{5}$

The course is about the joining of partial views and diverse voices that engage and shape MoD. We study development, aware that diverse ethics and politics provide the possibilities for unsettling views about the mutual and unequal structuring of knowledge and allow us to take risks not only in the classroom but in the world. 


\section{Disclosure statement}

No potential conflict of interest was reported by the author.

\section{Note on Contributor}

Wendy Harcourt is Chair of Gender, Diversity and Sustainable Development and 'Westerdijk Professor' at the International Institute of Social Studies of the Erasmus University in The Hague The Netherlands. At ISS/EUR she is Coordinator of the Research Group on Civic Innovation, Chair of the ISS Institute Council as well as Coordinator of the EU H2020-MSCAITN-2017 Marie Sklodowska-Curie Innovative Training Networks (ITN) WEGO (Well-being, Ecology, Gender, and Community).

\section{Notes}

1. Harcourt, "Making and Unmaking of Development."

2. Parra Heredia, "People, Personal Projects and the Challenges."

3. Private correspondence, 14 March 2017.

4. Harding, Sciences from below: Feminisms, Postcolonialities, and Modernities.

5. Haraway, "Situated Knowledges: The Science Question," 589.

\section{Bibliography}

Harcourt, W. "The Making and Unmaking of Development: Using Post-Development as a Tool in Teaching Development Studies." Third World Quarterly 38, no. 12 (2017): 2703-2718.

Haraway, D. "Situated Knowledges: The Science Question in Feminism as a Site of Discourse on the Privilege of Partial Perspective." Feminist Studies 14, no. 3 (1988): 575-599.

Harding, S. Sciences from below: Feminisms, Postcolonialities, and Modernities. Durham: Duke University Press, 2008.

Parra Heredia, J. D. “People, Personal Projects and the Challenging of Social Structures: A Contribution to the Reflection of Teaching Development Studies." Third World Quarterly (2018). doi:10.1080/0143 6597.2018.1460594 